\title{
Why did Israelis comply with COVID-19 Mitigation Measures during the initial first wave lockdown?
}

Anne Leonore de Bruijn*, Yuval Feldman+, Malouke Esra Kuiper*, Megan Brownlee*, Chris Reinders

Folmer*, Emmeke Kooistra*, Elke Olthuis*, Adam Fine ${ }^{\wedge}$, Benjamin van Rooij* ${ }^{*}<$

* University of Amsterdam, School of Law, Center for Law and Behavior

+Bar-Ilan University, Faculty of Law

\pm University of California, Irvine, School of Law

$\wedge$ Arizona State University, School of Criminology and Criminal Justice

$<$ corresponding author: bvanrooij@law.uci.edu or b.vanrooij@uva.nl

\begin{abstract}
This paper investigates why Israeli citizens complied with measures taken to mitigate the spread of the COVID-19 virus in early April. At the time, Israel had relatively stringent mitigation measures that encouraged people to stay at home and keep a safe social distance. The data of 411 adult participants, gathered using survey research, showed that overall, compliance levels at that time were high. It finds that compliance depended on a combination of moral factors, such as people's moral duty to obey the law and people's tendency to obey the law generally. In addition, people who had friends over 75 years old were more likely to comply. Furthermore, people were more likely to comply if they were able to do so, and less likely to violate if they did not have the opportunity to do so. The study did not find that fear of punishment (deterrence) was significantly associated with compliance. Overall, these findings are in line with studies conducted the United States, the United Kingdom, and the Netherlands.
\end{abstract}

Notes: This working paper offers a first look at the data collected before developing it into a fully theorized publication. It has not yet been peer reviewed. The authors declare that there is no conflict of interest.

\section{Introduction}

The COVID-19 pandemic has forced humanity to fundamentally change its behavior. Worldwide, governments have adopted measures, such as stay-at-home orders and social distancing rules, which were essential to slow the spread of the disease (Walker et al. 2020). During the first wave of the disease, most authorities adopted a combination of stay-at-home and social distancing rules, encouraging people to refrain from going outside (except for certain defined essential activities) and to keep a safe distance from people outside their own household. The results have shown an unprecedented behavioral change across most of the world. However, this compliance has come with tremendous social and economic costs, as many people lost their jobs, education was severely disrupted, and ordinary life was completely upended. This has created a unique and highly rare situation, in which we can see how different nations have responded to a new set of regulations at around the same time.

The present paper is part of a series of studies that seeks to understand what affected people's responses to comply with the COVID-19 mitigation measures during the first wave of the pandemic. Three previously 
published studies have analysed compliance with COVID-19 measures in early April, focusing on the United States ("US"), The United Kingdom ("UK"), and the Netherlands. Their findings showed that compliance levels were generally high in early April. They further showed that compliance did not rely on deterrence or threat of enforcement. Rather, compliance depended on people's individual characteristics and the situation they were in. In particular, people showed greater compliance when they had better impulse control (Netherlands and US), when they were better able to stay at home or keep a social distance, and when they lacked of opportunity to break the rules (most clearly in the US and Netherlands). On the other hand, intrinsic motivation also influenced compliance in these three countries. People were more likely to comply when they perceived greater obligation to obey the law (UK and Netherlands), when they saw many others complying (US and Netherlands), when they morally thought people should obey the measures (US and Netherlands), or were more afraid of the disease (Netherlands only).

The present study analyses what shaped compliance in Israel. It offers data that helps understand compliance with the COVID-19 measures in Israel. The study answers two crucial questions in relation to these mitigation measures. First, it studies to what extent people have complied with the measures taken. Second, it analyses which factors have played a role in shaping people's compliance.

The study thus adds a fourth country to our series of studies and further expands our understanding of compliance with mitigation measures during the first wave of the virus. Israel presents an interesting case to study compliance for several reasons. First, it has a longer history of dealing with national safety threats, and it stands to reason that Israeli citizens are likely more used to threats to their lives and also to emergency measures that curtail their freedom. ${ }^{1}$ Furthermore, the Israeli response has utilized wide-spread usage of technological surveillance, with secret service officials of Shin Beit tracking potential risks of people who have been in touch with confirmed patients ${ }^{2}$. To implement the measures, Israel has deployed the military, both to back up regular law enforcement as well as to provide large scale data that supports policy makers. ${ }^{3}$ Israel has two major minorities, the ultra-orthodox Jewish community and the Arab populations, both of whom have low trust in

\footnotetext{
${ }^{1}$ https://www.globes.co.i1/news/article.aspx?did=1001326419 (Hebrew)

2 Gross, Judah Ari (15 March 2020). "Government okays mass surveillance of Israelis' phones to curb coronavirus". The Times of Israel

${ }^{3} \mathrm{https}: / /$ www.nytimes.com/2020/04/12/world/middleeast/coronavirus-israel-mossad.html
} 
authorities ${ }^{4}$ and science, and live in high density communities ${ }^{5}$ with a greater risk for the virus to spread. In late March, there were reports that some ultra-orthodox Jews were directly violating the coronavirus rules ${ }^{6}$, while the virus spread eight times faster in their community than amongst other Israelis. ${ }^{7}$ Another interesting aspect is that research found that there are marked differences in individualism in Israel, with Arab and ultraorthodox citizens being more collectivist, and all other citizens being highly individualistic (Sagy et al. 2001, Mikulincer, Weller, and Florian 1993, Hofstede, Hofstede, and Minkov 1991). Relatedly, research has found that Israelis are not overly rule bound and have a lower sense of duty to obey the law (Yagil and Rattner 2002). Finally, Israel's political conditions were in a state of flux. After 18 months, three elections, and the indictment of the sitting Prime-Minister and key candidate of one of the leading parties, no government had been formed by early April, which was the time in which we conducted our study.

\section{Mitigation measures in Israel}

Israel's first response to COVID-19 was gradual and did not immediately start with a complete lockdown. Toward the end of February, especially given the presence of Israelis on the Diamond Princess cruise ship, ${ }^{8}$ measures toward the inevitable emergence of the virus began. First, 14 days of mandatory quarantine was implemented for people arriving from certain countries abroad, ${ }^{9}$ which was extended by March 9th to all countries. ${ }^{10}$ Second, on March 11, large group gatherings (with over 100 people) were banned, and on March 30 all gatherings with over 2 people were prohibited. ${ }^{11}$

\footnotetext{
${ }^{4}$ Yagil, Dana, and Arye Rattner. "Between commandments and laws: Religiosity, political ideology, and legal obedience in Israel." Crime, law and social change 38, no. 2 (2002): 185-209; Rosenbloom, Tova, Amit Shahar, and Amotz Perlman. "Compliance of Ultra-Orthodox and secular pedestrians with traffic lights in UltraOrthodox and secular locations." Accident Analysis \& Prevention 40, no. 6 (2008): 1919-1924.

${ }^{5}$ Shilhav, Yosseph. "The emergence of ultra-orthodox neighborhoods in Israeli urban centers." Local communities and the Israeli polity (1993): 157-187.

6 "Bnei Brak coronavirus cases near 1000 as Haredi cities hit hardest". Ynetnews. 2 April 2020. Retrieved 2 April 2020.

${ }^{7}$ https://www.nytimes.com/2020/04/15/world/middleeast/virus-israel-Orthodox-Bnei-Brak.html?auth=linkedfacebook

${ }^{8} \mathrm{https}$ ://www.haaretz.com/israel-news/.premium-fourth-israeli-diagnosed-with-coronavirus-on-stranded-cruiseship-1.8559229

${ }^{9}$ Israel bans foreigners coming from East Asian countries over virus fears". The Times of Israel. 17 February 2020.

${ }^{10}$ Israel declares 14-day quarantine for all arrivals". BBC News. 9 March 2020

${ }^{11}$ Haaretz (30 March 2020). "Coronavirus in Israel: Netanyahu Announces New Restrictions Barring Gatherings of Over Two".
} 
By early April, when we conducted our study, in anticipation of Passover (one of the most important and widely observed Jewish holidays, which in 2020 would start on April 8), Israel had taken a range of measures to slow the spread of the virus. People were generally ordered to stay at home and only go outside for essential activities. Exercise was only allowed within 100 meters from people's own houses and people were only allowed to go out with a maximum of two people per household. All public gatherings were banned, apart from some religious and family activities exceptions, such as small-scale funerals and circumcisions. Almost all retail shops were closed, and restaurants could only do deliveries. Israel also adopted strict social distancing restrictions, which mandated that people kept a two-meter distance from people outside of their residential household. Furthermore, people were not allowed to drive with more than two people in one car, except for emergencies.

Overall, the Israeli measures were relatively strict. According to University of Oxford's CORONAVIRUS Government Response Tracker, $\frac{12}{}$ Israel's calculated Stringency level on 7th of April 2020 was 90.74, significantly higher than for instance the US (72.69), Germany (73.15), the UK (75.93), or the Netherlands (79.63). See Table 1 below for comparisons.

\begin{tabular}{|l|c|}
\hline Country & $\begin{array}{l}\text { Stringency level } \\
\text { (April 7 2020) }\end{array}$ \\
\hline United States & 72.69 \\
\hline Germany & 73.15 \\
\hline Switzerland & 73.15 \\
\hline United Kingdom & 75.93 \\
\hline The Netherlands & 79.63 \\
\hline Belgium & 81.48 \\
\hline Spain & 85.19 \\
\hline France & 90.74 \\
\hline Israel & 90.74 \\
\hline
\end{tabular}

Table 1: Stringency level of COVID-19 mitigation measures on April 7, 2020, based on Oxford COVID-19 Government Response Tracker. ${ }^{13}$

\footnotetext{
${ }^{12}$ https://covidtracker.bsg.ox.ac.uk/stringency-scatter

${ }^{13}$ Hale, Thomas, Sam Webster, Anna Petherick, Toby Phillips, and Beatriz Kira (2020). Oxford COVID-19 Government Response Tracker, Blavatnik School of Government.
} 
Israeli authorities used several approaches to implement the measures. Violation of the measures was a criminal offence, punishable by fines and up to six months of imprisonment. By April 12, authorities had fined 25,837 citizens and businesses for violating the mitigation measures. Most fines were issued to people who were more than 100 meters away from their place of residence. Enforcement during the week of study, April 7-9th, was thus quite prevalent, haaving doubled from just a week earlier. ${ }^{14}$ Authorities also tried to ensure that communities could comply with the lockdown measures. For example, the Israeli military provided food to ultra-orthodox communities under lockdown and offered help to place patients from these communities in hotels outside of their homes. ${ }^{15}$ Authorities also sought to ensure that people to comply with stay-at-home and social distancing measures by closing down most retail and social venues. In this way, people did not have reasons to be outside, nor did they have opportunities to be with others.

Authorities also made moral appeals to comply. Prime-Minister Netanyahu said: "What it takes for each and every one of you, beyond complying with official guidelines, is strict self-discipline. If you don't enlist to protect yourself and your families, this will be a disaster." He added, "You have to stay home, stay in the houses stay alive, the danger lurks for each of you." ${ }^{16}$ Similarly, Health Ministry Director-General Moshe Bar Sim-Tov issued a statement to the media: "Follow our recommendations. The guidelines we gave today are very difficult to implement. We know this, and we feel that there is not enough internalization. We hope that reality will be positive, but we also understand that we need to prepare for other scenarios. The scenarios that happen in Italy and Spain can happen here as well. Our ability to really avoid such extreme scenarios depends on your behavior." ${ }^{17}$ Overall, the leading rhetoric employed by Israeli authorities was fear based, arguing that without the full compliance of the public, a health disaster would follow.

\section{Present study}

The present paper analyses the results from a survey conducted in an Israeli sample. The same survey was earlier used in a US sample (Van Rooij, de Bruijn, Reinders Folmer, et al. 2020), and focuses on two core contagion mitigation measures. The first are social distancing measures. Here, the survey looked at whether people

\footnotetext{
${ }^{14}$ https://www.calcalist.co.il/local/articles/0,7340,L-3807777,00.html (Hebrew)

15 https://www.al-monitor.com/pulse/originals/2020/04/israel-idf-soldiers-police-coronavirus-ultraorthodox.html

${ }^{16}$ https://news.walla.co.il/item/3348795 (Hebrew)

17 https://www.zman.co.il/91518/
} 
kept a safe distance from others (in the Israel this has been defined at two meters), and whether they refrained from meeting people outside of their own household. The second are stay-at-home-type measures. While there is variation in the exact details of such measures, their core substance is identical, namely, that people are to stay at home and only go out for what are deemed essential activities (which have been defined in the Israeli context as anything related to medial needs, food purchasing, and jobs that have been defined as essential). To study compliance with these measures in the Israel, the survey used self-reported measures of compliance by asking respondents to report the frequency in which they have engaged in the behaviors that are desired (or prohibited) by the measures.

In addition to examining the level of compliance with these measures, the study also explored the processes that may shape compliance. To do so, we drew from insights about compliance, and why people obey or break rules, from psychology, criminology, sociology, and economics (Van Rooij and Sokol 2021 (Forthcoming), Friedman 2016, Feldman 2018). This is different from previous COVID-19 compliance studies that have not reported what shapes variation in compliance (I\&O Research and Universiteit Twente 2020, Fetzer et al. 2020), or only measured intentional behavior (Lunn et al. 2020, Everett et al. 2020). Other studies that have assessed variation in compliance with COVID-19 mitigation measures found that compliance is shaped by general personality characteristics, perceived social norms and attitudes towards the measures (Bogg and Milad 2020), political orientation (Kushner Gadarian, Wallace Goodman, and Pepinsky 2020), trust in science (Plohl and Musil 2020), and fear of the virus or attitudes about its severity (Oosterhoff and Palmer 2020, Harper et al. 2020), but have not focused specifically on variables that are known to explain variation in compliance (Van Rooij and Sokol 2021 (Forthcoming)). The independent variables that are included in the present study comprise substantive moral support for the measures (e.g., Tyler 1997, 2006), costs of compliance (e.g., Paternoster and Simpson 1993, Donovan and Blake 1992, Botchkovar, Tittle, and Antonaccio 2009), deterrence (e.g., Nagin 2013, Apel 2013), capacity to comply (e.g., Van Rooij 2021 (Forthcoming)) and opportunity to violate the measures (Cohen and Felson 1979, Clarke 1980), impulsivity (Gottfredson and Hirschi 1990, Pratt and Lloyd 2021 (forthcoming)), descriptive social norms (e.g., Cialdini and Goldstein 2004, Schultz et al. 2007), obligation to obey the law (e.g., Fine et al. 2016, Posch et al. 2020, Tyler 2017), and political orientation (e.g., Prior 2013, Spohr 2017). For a detailed reasoning behind each of these variables, see Van Rooij, de Bruijn, Reinders Folmer, et al. (2020).

\section{Methods}




\section{Participants}

A total of $N=509$ Israeli residents completed the survey in Qualtrics. Participants were recruited through Panel4All, which is a survey company that has a panel consisting of over 30 thousand active panellists. For this study, a panel of 100,000 participants was used and a representative sample was drawn based on age, gender, religiosity, and residency. The data was collected from April 7 - 9th, 2020. Participants were paid nominal fee for their participation. Eleven participants were excluded because they provided professional care for COVID-19 patients, and 94 participants were excluded because they failed the attention check. Table 1 shows the characteristics of the final sample $(N=411)$.

Table 1.

Sample characteristics for Israel $(N=411)$.

\begin{tabular}{|c|c|}
\hline & Mean $(S D)$ \\
\hline Age & $40.36(15.01)$ \\
\hline \multicolumn{2}{|l|}{ Gender } \\
\hline Male & $47.9 \%$ \\
\hline Female & $52.1 \%$ \\
\hline \multicolumn{2}{|l|}{ Nationality } \\
\hline Jewish & $84.4 \%$ \\
\hline Arabic & $14.4 \%$ \\
\hline Other & $1.2 \%$ \\
\hline \multicolumn{2}{|l|}{ Religion } \\
\hline Secular & $40.6 \%$ \\
\hline Traditional & $29.0 \%$ \\
\hline Orthodox & $8.8 \%$ \\
\hline Ultra-orthodox & $6.1 \%$ \\
\hline \multicolumn{2}{|l|}{ Education } \\
\hline Some high school, no diploma & $9.2 \%$ \\
\hline High school graduate, diploma & $23.1 \%$ \\
\hline Some college credit, no degree & $6.8 \%$ \\
\hline Associate degree & $14.6 \%$ \\
\hline Bachelor's degree & $30.2 \%$ \\
\hline Master's degree & $14.8 \%$ \\
\hline $\begin{array}{l}\text { Professional degree - } \\
\text { Medicine/Dentistry } \\
\text { Doctorate degree }\end{array}$ & $\begin{array}{l}0.2 \% \\
1.0 \%\end{array}$ \\
\hline \multicolumn{2}{|l|}{ Political orientation } \\
\hline Very progressive & $25.1 \%$ \\
\hline Slightly progressive & $26.3 \%$ \\
\hline Slightly conservative & $21.9 \%$ \\
\hline Very conservative & $8.8 \%$ \\
\hline
\end{tabular}




\section{Materials}

Control variables. The following descriptive statistics were recorded: Age, gender, nationality, religion, education, insurance status, number of people in household, number of children, and social economic status before and after COVID-19 based on the MacArthur Scale of Subjective Social Status; Adler et al. 2000. Participants also had to indicate whether they provided professional care for COVID-19 patients, whether they had visited friends or family over the age of 75 on a regular basis prior to the outbreak of the virus, and whether they or anyone they knew had underlying health issues that made them more at risk for contracting COVID-19. In addition, participants were asked to indicate their trust in science and trust in media, both measures on a single item that was adapted from McCright et al. (2013), using a 5-point Likert scale ranging from (1) "completely distrust” to (5) "completely trust" Political orientation was measured with a single item adapted from Hasson et al. (2018), Fine, Rowan, and Simmons (2019), Wojcik et al. (2015) that asked participants to indicate their political orientation on a 4-point scale ranging from (1) "very progressive" to (4) "very conservative."

Compliance with COVID-19 measures. Respondents' compliance with two key COVID-19 mitigation measures was measured, namely "social distancing” and "stay at home” measures. Four items measured whether participants complied with social distancing measures. Item 1, 3, and 4 were reverse coded. One item measured whether participants complied with stay at home measures. Answers were recorded on a 7point Likert scale ranging from (1) “never” to (7) “always.” For all five items, higher scores indicated greater compliance. As all items referred to compliance with mitigation measures, we combined the five items into a single variable that captured overall compliance with COVID-19 measures $(\alpha=.64)$.

However, as the scale of the five items showed poor internal consistency, we decided to use a binary measure. First, each item was binary coded. Scores from 1-6 were coded as “0” (non-compliant), and score 7 was coded as " 1 " (compliant). A total score of the five binary items was produced, that varied from 0 (noncompliant on all five items) to 5 (compliant on all five items).

Substantive moral support. Substantive moral support was measured on three subscales: perceived threat, specific moral alignment, and support for current policies.

Perceived threat. Perceived threat was measured using two items, where participants indicated to what extent they believed the Coronavirus was a threat to themselves or the general health of the public. Answers were recorded on a 7-point Likert scale ranging from (1) "very strongly disagree" to (7) "very strongly agree." The two items were closely associated $(r=.56)$, and therefore combined into a single scale measure. 
Specific moral alignment. Specific moral alignment was measured using two items, where participants indicated to what extent they believed people should follow the COVID-19 mitigation measures. Answers were recorded on a 7-point Likert scale ranging from (1) "very strongly disagree" to (7) "very strongly agree." The two items were closely associated $(\mathrm{r}=.86)$, and therefore combined into a single scale measure.

Support for current policies. Support for current policies was measured using three items $(\alpha=.86)$, where participants indicated to what extent they supported the authorities in adopting the COVID-19 mitigation measures. Answers were recorded a 7-point Likert scale ranging from (1) "very strongly disagree" to (7) "very strongly agree." Mean scores were calculated and higher values indicated more support for the authorities adopting the COVID-19 measures. However, item 3 correlated poorly with the other two items. If removed, Cronbach's alpha rose to $\alpha=.86$, and the item was therefore excluded from further analysis.

Costs of compliance and strain. Costs of compliance and strain were measured on two sub-scales, costs of compliance, and negative emotions.

Costs of compliance Participants indicated on five items $(\alpha=.77)$ how likely it was that compliance with the COVID-19 mitigation measures would have a negative impact on their routine Answers were recorded a 7point Likert scale ranging from (1) "extremely unlikely" to (7) "extremely likely."

Negative emotions Negative emotions due to COVID-19 was measured on six items $(\alpha=.87)$ assessing different negative emotions. Answers were recorded on a 7-point Likert scale ranging from (1) "very strongly disagree" to (7) "very strongly agree." Mean scores were calculated and higher values indicated more negative emotions.

Deterrence. Deterrence was measured for the two COVID-19 mitigation measures, that is social distancing measures and stay at home measures. First, two items measured certainty of apprehension and punishment for violating COVID-19 measures. As correlation analysis indicated a high overall between both items, they were combined into a single scale measure $(\alpha=.87)$. Answers were recorded on a 7-point Likert scale ranging from (1) "extremely improbable" to (7) "extremely probable." The last item measured severity of punishment $(\alpha=.94)$, where participants indicated how much suffering punishment for violating COVID-19 measures would cause them. Answers were recorded on a 6-point Likert scale ranging from (1) "extreme suffering" to (6) "no suffering at all." 
Capacity to comply. Three items $(\alpha=.62)$ measured to what extent participants were practically able to comply with the COVID-19 mitigation measures. Answers were recorded on a 7-point Likert scale ranging from (1) "very strongly disagree" to (7) "very strongly agree." Item 2 correlated poorly with the other two items. If removed, Cronbach's alpha rose to $\alpha=.81$, and the item was therefore excluded from further analysis.

Opportunity to violate. Five items $(\alpha=.86)$ measured to what extent participants had the opportunity to violate the COVID-19 mitigation measures. Answers were recorded on a 7-point Likert scale ranging from (1) "very strongly disagree" to (7) "very strongly agree."

Impulsivity. Impulsivity was measured using a subset of five items $(\alpha=.75)$ taken from the 8 -item impulse control subscale from the Weinberger Adjustment Inventory WAI; Weinberger and Schwartz 1990. Answers were recorded on a 5-point Likert scale ranging from (1) "false" to (5) "true." Item 5 was reverse coded and means were calculated such that higher scores indicated greater impulsivity.

Descriptive Social norms. Participants rated to what extent people they know comply with the COVID19 measures, both social distancing and lockdown measures (one item for each type of measure, $\alpha=.97$ ). Answers were recorded on a 7-point Likert scale ranging from (1) "very strongly disagree" to (7) "very strongly agree." Higher scores indicated greater compliant descriptive social norms.

Obligation to obey the law (OOL). Obligation to obey the law was measured using three sub-scales: Normative obligation to obey the law, non-normative obligation to obey, and procedural justice.

Normative obligation to obey. Normative obligation to obey was measured with a single item, "Ifeel like it is sometimes okay to break the law.” Answers were recorded on a 7-point Likert scale ranging from (1) "strongly agree" to (7) "strongly disagree." The item was created for the current study based on extant work by e.g., Estévez and Emler 2010, Reisig, Bratton, and Gertz 2007, Fine et al. 2020. Higher scores indicated greater normative obligation to obey the law.

Non-normative obligation to obey. Non-normative obligation was measured using a single item "I only obey the authorities handling the Coronavirus because I am afraid of them." (adapted from Posch et al. (2020), Tankebe, Reisig, and Wang (2016)). Answers were recorded on a 7-point Likert scale ranging from (1) "very strongly disagree" to (7) “very strongly agree." Higher scores indicated greater non-normative obligation to obey.

Procedural justice (PJ). Procedural justice was measured using items adapted from prior measures of procedural justice used in the study of police (Baker and Gau 2018, Gau 2014, Tyler 1997, Wolfe et al. 2016). 
Three items $(\alpha=.93)$ measured procedural justice in creating the COVID-19 mitigation measures. Four items ( $\alpha$ $=.92$ ) measured procedural justice in enforcing the COVID-19 mitigation measures. Answers were recorded on a 7-point Likert scale ranging from (1) "very strongly disagree” to (7) "very strongly agree." A combined mean score for procedural justice in both creating and enforcing the COVID-19 mitigation measures $(\alpha=.95)$ was calculated, with higher values indicating higher procedural justice.

\section{Results}

\section{Compliance with COVID-19 measures}

Table 2 shows the descriptive statistics of the items that measured compliance with COVID-19 measures. For all items means were considerably large, indicating that overall, participants self-reported high rates of compliance.

\section{Table 2.}

Descriptive statistics of Compliance with COVID-19 measures $(N=411)$

\begin{tabular}{|c|c|c|c|}
\hline Item & Mean (SD) & Scale & Binary (1) \\
\hline \multicolumn{4}{|l|}{ Since the authorities took measures to contain the Coronavirus: } \\
\hline \multicolumn{4}{|l|}{ Social distancing } \\
\hline 1. I still meet people outside of my direct household*. & $5.69(1.53)$ & $1-7$ & $35.0 \%$ \\
\hline 2. I keep a safe distance from people outside of my direct household. & $5.92(1.48)$ & $1-7$ & $47.7 \%$ \\
\hline 3. I still visit others (friends, relatives) outside of my direct household*. & $6.48(1.04)$ & $1-7$ & $67.9 \%$ \\
\hline 4. I still allow others (friends, relative) to visit my direct household*. & $6.47(1.06)$ & $1-7$ & $68.9 \%$ \\
\hline \multicolumn{4}{|l|}{ Stay at home } \\
\hline $\begin{array}{l}\text { 1. I have stayed at home after I was ordered to do so, apart from engaging } \\
\text { in essential activities (e.g., grocery shopping, medical appointments). }\end{array}$ & $6.22(1.06)$ & $1-7$ & $60.3 \%$ \\
\hline Combined binary measure & $2.80(1.67)$ & $0-5$ & \\
\hline
\end{tabular}




\section{Descriptive statistics}

Table 3 shows the descriptive statistics of some of the control variables. Table 4 shows the descriptive statistics of the independent variables.

Table 3.

Descriptive statistics of control variables $(N=411)$.

\begin{tabular}{llc}
\hline Variables & $\begin{array}{l}\text { Descriptive } \\
\text { Statistics }\end{array}$ & Scale \\
\hline SES pre-COVID-19 & $4.93(1.62)$ & $1-10$ \\
SES post-COVID-19 & $5.26(1.94)$ & $1-10$ \\
Friends/family 75+ & $49.1 \%$ & \\
Health issues self & $19.2 \%$ & \\
Health issues others & $71.3 \%$ & \\
Trust in science & $4.10(0.92)$ & $1-5$ \\
Trust in media & $3.26(1.19)$ & $1-5$ \\
\hline
\end{tabular}

Table 4.

Descriptive statistics of independent variables $(N=411)$

\begin{tabular}{llc}
\hline Variables & M (SD) & Scale \\
\hline Substantive moral alignment & & \\
$\quad$ Perceived threat & $5.22(1.38)$ & $1-7$ \\
$\quad$ Specific moral alignment & $6.39(0.98)$ & $1-7$ \\
$\quad$ Support current policies & $5.04(1.44)$ & $1-7$ \\
Costs of compliance & $3.52(1.45)$ & $1-7$ \\
Negative emotions & $3.98(1.33)$ & $1-7$ \\
Deterrence & & \\
$\quad$ Certainty & $4.28(0.33)$ & $1-7$ \\
$\quad$ Severity & $3.48(1.43)$ & $1-6$ \\
Capacity to comply & $5.99(1.24)$ & \\
$\quad$ Practical capacity to comply & $2.44(1.37)$ & $1-7$ \\
$\quad$ Knowledge & $1.97(0.81)$ & $0-7$ \\
$\quad$ Clarity of current measures & $5.44(1.34)$ & $1-7$ \\
Opportunity to comply & & $1-7$ \\
Impulsivity & $5.70(1.37)$ & $1-5$ \\
Descriptive social norms & $3.03(1.67)$ & $1-7$ \\
OOL and PJ & $5.85(1.06)$ & \\
$\quad$ Normative OOL & $5.70(1.37)$ & $1-7$ \\
Non-normative OOL & $5.22(1.38)$ & $1-7$ \\
PJ & $6.39(0.98)$ & $1-7$ \\
Political orientation & $5.04(1.44)$ & $1-5$ \\
\hline Note. Political oriention $N=337$. &
\end{tabular}

Note. Political orientation $N=337$.

\section{Correlations}

Table 5 shows the correlations between the binary sum compliance measure and the control variables. Table 6 shows the correlations between the binary sum compliance measure and the independent variables. 
Table 5.

Kendall's tau correlations of control variables $(N=411)$

\begin{tabular}{|c|c|c|c|c|c|c|c|c|c|c|c|c|c|c|}
\hline & 1. & 2. & 3. & 4. & 5. & 6. & 7. & 8. & 9. & 10. & 11. & 12. & 13. & 14. \\
\hline 1. Gender & - & & & & & & & & & & & & & \\
\hline 2. Education & -.084 & - & & & & & & & & & & & & \\
\hline 3. $N$ Household & -.066 & $-.079 *$ & - & & & & & & & & & & & \\
\hline 4. $N$ Children & .012 & .076 & $.424 * *$ & - & & & & & & & & & & \\
\hline 5. Religion & .007 & $-.105^{*}$ & $.244 * *$ & $.149 * *$ & - & & & & & & & & & \\
\hline 6. SES pre-COVID-19 & $.115 * *$ & $-.099 *$ & -.036 & -.048 & -.003 & - & & & & & & & & \\
\hline 7. SES post-COVID-19 & $.164 * *$ & $-.105 * *$ & -.018 & .050 & .002 & $.591 * *$ & - & & & & & & & \\
\hline 8. Friends/family $75+$ & -.060 & $.131 * *$ & -.027 & .083 & -.061 & $-.148 * *$ & -.078 & - & & & & & & \\
\hline 9. Health issues self & -.088 & .085 & $-.167 * *$ & $-.091 *$ & -.001 & .061 & $.087 *$ & .027 & - & & & & & \\
\hline 10. Health issues other & $.155^{* *}$ & $.094 *$ & -.056 & .041 & -.052 & -.017 & .032 & $.204 * *$ & $.187 * *$ & - & & & & \\
\hline 11. Trust in science & $-.136 * *$ & $.082 *$ & -.076 & -.017 & $-.118^{*}$ & $-.092 *$ & $-.111 * *$ & .040 & .059 & .088 & - & & & \\
\hline 12. Trust in media & .056 & -.019 & -.028 & -.017 & $-.168 * *$ & -.023 & -.046 & .051 & .020 & .062 & $.303 * *$ & - & & \\
\hline 13. Political orientation & .056 & -.058 & $.121 * *$ & .053 & $.430 * *$ & -.063 & -.065 & -.068 & .016 & -.043 & $-.093 *$ & $-.205 * *$ & - & \\
\hline 14. Compliance & .083 & -.046 & -.023 & $-.088 *$ & .046 & .046 & .031 & -.072 & $.102 *$ & .044 & $.091 *$ & .035 & -.019 & - \\
\hline
\end{tabular}

Note. ${ }^{*}$ Correlation is significant at the .05 level. ${ }^{* *}$ Correlation is significant at the .01 level. Religion: $N=347$. Political orientation: $N=337$. 


\section{Table 6}

Kendall's tau correlations of independent variables $(N=411)$.

\begin{tabular}{|c|c|c|c|c|c|c|c|c|c|c|c|c|c|c|c|}
\hline & 1. & 2. & 3. & 4. & 5. & 6. & 7. & 8. & 9. & 10. & 11. & 12. & 13. & 14. & 15 . \\
\hline 1. Perceived threat & - & & & & & & & & & & & & & & \\
\hline $\begin{array}{l}\text { 2. Specific moral } \\
\text { alignment }\end{array}$ & $.340 * *$ & - & & & & & & & & & & & & & \\
\hline $\begin{array}{l}\text { 3. Support for current } \\
\text { policies }\end{array}$ & $.157 * *$ & $.260 * *$ & - & & & & & & & & & & & & \\
\hline 4. Costs of compliance & .013 & -.061 & $-.148 * *$ & - & & & & & & & & & & & \\
\hline 5. Negative emotions & $.159 * *$ & .012 & -.007 & $.169 * *$ & - & & & & & & & & & & \\
\hline 6. Impulsivity & -.047 & $-.180 * *$ & -.040 & $.140 * *$ & $.171^{* *}$ & - & & & & & & & & & \\
\hline $\begin{array}{l}\text { 7. Deterrence } \\
\text { certainty }\end{array}$ & $.078 *$ & $.128 * *$ & .016 & $.096 * *$ & $.090 * *$ & -.053 & - & & & & & & & & \\
\hline 8. Deterrence severity & -.065 & .001 & -.043 & $-.105 * *$ & $-.125^{* *}$ & -.049 & $-.109 * *$ & - & & & & & & & \\
\hline 9. Social norms & -.002 & $.201 * *$ & $.120 * *$ & -.058 & -.024 & $-.121 * *$ & $.175 * *$ & -.037 & - & & & & & & \\
\hline $\begin{array}{l}\text { 10. Capacity to } \\
\text { comply }\end{array}$ & .073 & $.350 * *$ & $.090 *$ & .016 & .027 & $-.134 * *$ & $.150 * *$ & .037 & $.292 * *$ & - & & & & & \\
\hline $\begin{array}{l}\text { 11. Opportunity to } \\
\text { violate }\end{array}$ & $-.119 * *$ & $-.286^{* *}$ & $-.109 * *$ & -.009 & .018 & $.165^{* *}$ & $-.077 *$ & -.038 & $-.182 * *$ & $-.325 * *$ & - & & & & \\
\hline 12. Normative OOL & $.170 * *$ & $.348 * *$ & $.166^{* *}$ & -.062 & -.034 & $-.186^{*}$ & $.086^{*}$ & .031 & $.201 * *$ & $.230 * *$ & $-.271 * *$ & - & & & \\
\hline $\begin{array}{l}\text { 13. Non-normative } \\
\text { OOL }\end{array}$ & $-.080^{*}$ & $-.221 * *$ & -.065 & $.085^{*}$ & $.174 * *$ & $.182 * *$ & .043 & $-.107 * *$ & $-.119 * *$ & $-.168 * *$ & $.145^{* *}$ & $-.155^{* *}$ & - & & \\
\hline 14. PJ & .018 & $.114^{* *}$ & .020 & -.067 & $-.074 *$ & $-.111 * *$ & .053 & .011 & $.193 * *$ & $.201 * *$ & -.047 & $.077 *$ & $-.151 * *$ & - & \\
\hline 15. Compliance & $.153 * *$ & $.370 * *$ & $.087 *$ & -.028 & .020 & $-.151 * *$ & $.148^{* *}$ & .050 & $.270^{*}$ & $.475 * *$ & $-.373 * *$ & $.275^{* *}$ & $-.149 * *$ & $.140 * *$ & - \\
\hline
\end{tabular}

Note. ${ }^{*}$ Correlation is significant at the .05 level. ${ }^{* *}$ Correlation is significant at the .01 level. 


\section{Data analysis}

Multivariable Poisson regression modeling techniques were used to identify independent predictors of compliance. This method is appropriate when analyses are conducted for data sets having count-dependent variables (Coxe, West, \& Aiken, 2009). Control variables that were used in the theoretical models below were: gender, number of children, $75+$ friends or family, and trust in science.

A multivariable Poisson regression was run to predict compliance based on: perceived threat, moral belief, support for current policies, costs of compliance, negative emotions, impulsivity, likelihood of punishment, severity of punishment, descriptive social norms, capacity to comply, opportunity to comply, perceived general obligation to obey the law, fear of authorities, and procedural justice (total score).

For every one unit increase in moral belief, compliance would be expected to increase by a factor of $1.12(95 \% \mathrm{CI}, 1.02$ to 1.22$)$, while holding all other variables in the model constant, a statistically significant result, $p=.018$. For every one unit increase in capacity to comply, compliance would be expected to increase by a factor of $1.21(95 \% \mathrm{CI}, 1.13$ to 1.30$)$, while holding all other variables in the model constant, a statistically significant result, $p=.000$. For every one unit increase in opportunity to comply, compliance would be expected to decrease by a factor of $0.91(95 \% \mathrm{CI}, 0.87$ to 0.96 ), while holding all other variables in the model constant, a statistically significant result, $p=.000$. For every one unit increase in perceived general obligation to obey the law, compliance would be expected to increase by a factor of $1.06(95 \% \mathrm{CI}, 1.01$ to 1.12$)$, while holding all other variables in the model constant, a statistically significant result, $p=.029$. 
Table 7

Poisson Regression Multivariable Model

\begin{tabular}{|c|c|c|c|c|c|c|c|}
\hline \multirow[b]{2}{*}{ Predictor } & \multirow[b]{2}{*}{$\mathrm{B}$} & \multirow[b]{2}{*}{$\mathrm{SE}$} & \multicolumn{2}{|c|}{$\begin{array}{l}\text { 95\% Confidence } \\
\text { Interval }\end{array}$} & \multirow[b]{2}{*}{$\begin{array}{l}\text { Test } \\
\text { statistic }\end{array}$} & \multirow[b]{2}{*}{$P$ value } & \multirow[b]{2}{*}{$\operatorname{Exp}(B)$} \\
\hline & & & Lower & Upper & & & \\
\hline Intercept & -1.21 & 0.44 & -2.07 & -0.36 & -2.78 & $.005 * *$ & 0.30 \\
\hline Gender & -0.05 & 0.06 & -0.18 & 0.07 & -0.82 & .413 & 0.95 \\
\hline Children & -0.04 & 0.03 & -0.10 & 0.01 & -1.65 & .099 & 0.96 \\
\hline $75+$ friends & -0.13 & 0.06 & -0.25 & -0.01 & -2.18 & $.029 *$ & 0.88 \\
\hline Trust in science & 0.01 & 0.04 & -0.06 & 0.08 & 0.29 & .775 & 1.01 \\
\hline Perceived threat & 0.03 & 0.02 & -0.02 & 0.07 & 1.15 & .249 & 1.03 \\
\hline Moral belief & 0.11 & 0.05 & 0.02 & 0.20 & 2.37 & $.018^{*}$ & 1.12 \\
\hline Support for current policies & -0.02 & 0.02 & -0.06 & 0.02 & -0.90 & .368 & 0.98 \\
\hline Costs of compliance & -0.01 & 0.02 & -0.05 & 0.03 & -0.55 & .580 & 0.99 \\
\hline Negative emotions & 0.03 & 0.02 & -0.02 & 0.07 & 1.07 & .286 & 1.03 \\
\hline Impulsivity & -0.03 & 0.04 & -0.11 & 0.05 & -0.77 & .442 & 0.97 \\
\hline Deterrence certainty & 0.02 & 0.02 & -0.01 & 0.06 & 1.33 & .184 & 1.02 \\
\hline Deterrence severity & 0.02 & 0.02 & -0.02 & 0.06 & 1.10 & .272 & 1.02 \\
\hline Social norms & 0.04 & 0.02 & -0.01 & 0.09 & 1.48 & .139 & 1.04 \\
\hline Capacity to comply & 0.19 & 0.03 & 0.13 & 0.26 & 5.57 & $.000 * * *$ & 1.21 \\
\hline Opportunity to violate & -0.09 & 0.03 & -0.14 & -0.05 & -3.54 & $.000 * * *$ & 0.91 \\
\hline Normative OOL & 0.06 & 0.03 & 0.01 & 0.11 & 2.18 & $.029 *$ & 1.06 \\
\hline Non-normative OOL & -0.01 & 0.02 & -0.04 & 0.03 & -0.31 & .759 & 0.99 \\
\hline PJ & -0.02 & 0.03 & -0.08 & 0.05 & -0.50 & .618 & 0.98 \\
\hline
\end{tabular}

Note. ${ }^{*} \mathrm{p}<.05, * * \mathrm{p}<.01, * * * \mathrm{p}<.001$. 


\section{Discussion}

The descriptive findings suggest a high overall level of compliance with the COVID-19 mitigation measures in Israel. This is in line with Google COVID-19 Community Mobility Reports from April 7th, which show that, at the time of the survey, Israelis indeed were far less mobile than before the measures were adopted, and thus seemed to adjust their behavior to comply with the lockdown measures. The reports also show a $71 \%$ decline in travel to places of retail and recreation, a $25 \%$ decline in grocery shopping trips, a $54 \%$ decline in visits to parks, a $49 \%$ decline in public transit, and a $62 \%$ decline in commuted to work.

In this paper, we generally see that three factors played a role in affecting compliance. The first factor that was related to compliance was morality; people were more likely to comply with the rules if they thought people had a moral obligation to obey these particular rules. In other words, people were more compliant where they showed moral support for the rules. Further, compliance was higher when people generally felt less likely to break the law, which reflects a higher obligation to obey the law. This taken together means that people complied either because they morally supported compliance with these rules or because they generally thought people should obey legal rules. These findings are striking, as earlier research has found that Israelis had a relatively low "duty to obey the law" (Yagil and Rattner 2002).

Such sense of duty to obey specific rules or obey rules in general may have several sources. Generally, we know that people's perceptions of the legal system matters. The more fair and just people view the lawmaking and enforcement process, the more likely they will comply with its rules (Walters and Bolger 2019). However, in this study, we do not find a significant correlation between normative obligation to obey the law and procedural justice. We also know that duty to obey the law associates with particular forms of moral reasoning some individuals may have more than others, such as moral disengagement and moral firmness (Fine et al. 2020, Fine et al. 2016). Thus, although we did not study this here, differences in moral reasoning may well have played a role in compliance here.

The second factor that was related to compliance was whether people had friends that were 75 years or older. From this, it becomes clear that people care about the elderly people whom they know. We did not find a significant association between compliance and perceived threat to people's own health, health of friends and family, or health in general. In particular, in this survey's sample, people's general fear about health did not play a role in compliance. Rather, respondent's fear regarded the health of close elderly people with an increased risk of severe illness from COVID-19. This is somewhat different from findings elsewhere, insofar as a perceived sense of 
solidarity seemingly shaped compliance. For example, in the UK, Jackson et al., (2020) showed that messages such as "we are in this together," were the strongest predictors of lockdown compliance in a convenience sample of UK residents: a sense of common fate, a shared identity, and acting for the common good.

The third factor that related to compliance was situational circumstances that people were experiencing. People were more likely to comply if they had greater capacity to do so, and less likely to violate the rules if they did not have the opportunity to do so. This is in line with earlier findings from the US, the UK, and the Netherlands (Kooistra et al. 2020, Kuiper et al. 2020, van Rooij, de Bruijn, Folmer, et al. 2020), from the surveys conducted in early April.

Furthermore, the findings of this study show that deterrence did not play a significant role in compliance; People who perceived a higher certainty and severity of punishment were not more likely to comply than those with lower perceptions of certainty and severity of punishment. While this does not mean that deterrence did not play a role at all, or that sanctions were not necessary, it does indicate that the level of sanctions that existed did not relate to compliance. This finding is again in line with findings from the US, the UK, and the Netherlands during the same period ( Kooistra et al. 2020, Kuiper et al. 2020, van Rooij, de Bruijn, Folmer, et al. 2020).

\section{Conclusion}

The data in this paper illustrates how, during the first wave in the spread of COVID-19 in early April, there was a high level of self-reported compliance with COVID-19 mitigation measures in Israel. It shows that such compliance depended on people's moral sense of duty to obey the law, the care people had for elderly friends, and the situation they found themselves in with regard to being able to comply and having the opportunity to violate the rules. It shows a pattern that is similar to other studies conducted in the US, the UK, and the Netherlands. It shows that intrinsic motivation and situational variables were at play, but extrinsic motivations, like deterrence, were not. This paper thus shows how in Israel, a similar pattern as we saw in our studies in the US, UK and the Netherlands played a role in an unprecedented behavioral change directed by governmental measures. It helps us to understand the reasons why compliance was high in the early phase of the mitigation measures and lockdown, and also suggests how important it is for governments to provide people with both the justifications and the means for complying with the regulations. The importance of knowing an elderly person and the contribution of morality should also inform policy makers in how they "sell" the need to comply with the COVID-19 regulation. Causing people to think about 
the "identified victim" who might be harmed by one's non-compliance might increase peoples' moral awareness to the importance of following the COVID rules (Kogut and Ritov 2005). Moreover, the data shows how important practical support is for compliance. Capacity played a major role in compliance and the easier it was to comply, the more people did so. In many families in Israel, people are not able to isolate themselves from their family members or keep a safe distance. Therefore, based on the findings of this study, it might be important to invest the needed hospitality facilities which would allow people who do not have the physical capacity to comply with social distancing in their own homes. Future studies should look carefully at how matters changed since early April, as in Israel there seems to have been a decline in compliance. ${ }^{18}$ Here it will be interesting to see whether the influences that shaped compliance in early April changed, whether people's moral support for the policies and their capacity to comply declined, or whether over the course of the pandemic the influences on compliance themselves changed.

\footnotetext{
${ }^{18}$ Hale, Thomas, Sam Webster, Anna Petherick, Toby Phillips, and Beatriz Kira (2020). Oxford COVID-19
}

Government Response Tracker, Blavatnik School of Government. Data use policy: Creative Commons Attribution CC BY standard;

Google LLC "Google COVID-19 Community Mobility Reports". https://www.google.com/covid19/mobility/ Accessed: <07/04/20>;

"Masks are a rare sight in Israeli public spaces, despite regulations" Ynet, June 20, 2020.

Jeffry, Nathan. "Israelis ditch masks, even as massive study says they cut infection risk by $85 \%$ " The Times of Israel, June 9, 2020.

Kavaler, Tara. "Public transportation safety questioned amid Israel's reopening." The Jerusalem Post, June 1, 2020.; Zagrizek, Assaf. "Passengers flout mask order on public transport despite spread of virus." Ynet, June 21, 2020.; Jaffe-Hoffman, Maayan. "Event halls to open Sunday despite consistent coronavirus surge" The Jerusalem post, June 14, 2020.;

Staff, Toi. "Israel to step up mask enforcement as virus cases spike overnight." The Times of Israel, June 10, 2020 Plocker, Severe. "Israel brought a second coronavirus wave upon itself." Ynet, May 31, 2020.

Zagrizek, Assaf. "public transport resumption blamed fot new COVID-19 cases" Ynet May 31,2020. 


\section{References}

Adler, Nancy E, Elissa S Epel, Grace Castellazzo, and Jeannette R Ickovics. 2000. "Relationship of subjective and objective social status with psychological and physiological functioning: Preliminary data in healthy white women." Health Psychology 19 (6):586.

Apel, Robert. 2013. "Sanctions, perceptions, and crime: Implications for criminal deterrence." Journal of quantitative criminology 29 (1):67-101.

Baker, Thomas, and Jacinta M Gau. 2018. "Female offenders' perceptions of police procedural justice and their obligation to obey the law." Crime \& Delinquency 64 (6):758-781.

Bogg, T., and E. Milad. 2020. "[Pre-print]. Slowing the Spread of COVID-19: Dempgraphic, personality an social cognition predictors of guideline adherence in a representative U.S. sample.". doi: 10.31234/osf.io/yc2gq.

Botchkovar, Ekaterina V, Charles R Tittle, and Olena Antonaccio. 2009. "General strain theory: Additional evidence using cross-cultural data." Criminology 47 (1):131-176.

Cialdini, Robert B., and Noah J. Goldstein. 2004. "Social influence: compliance and conformity." Annual Review of Psychology 55:591-621. doi: 10.1146/annurev.psych.55.090902.142015.

Clarke, Ronald VG. 1980. "" Situational" Crime Prevention: Theory and Practice." The British Journal of Criminology 20 (2):136-147.

Cohen, Lawrence E, and Marcus Felson. 1979. "Social change and crime rate trends: A routine activity approach." American sociological review 44 (4):588-608.

Donovan, Jenny L, and David R Blake. 1992. "Patient non-compliance: deviance or reasoned decisionmaking?" Social science \& medicine 34 (5):507-513.

Estévez, Estefanía, and Nicholas P Emler. 2010. "A structural modelling approach to predict adolescent offending behaviour from family, school and community factors." European Journal on Criminal Policy and Research 16 (4):207-220.

Everett, JAC, C Colombatto, V Chituc, WJ Brady, and MJ Crockett. 2020. "[Pre-print]. The effectiveness of moral messages on public health behavioral intentions during the COVID-19 pandemic." doi: 10.31234/osf.io/9yqs8.

Feldman, Yuval. 2018. The law of good people: Challenging states' ability to regulate human behavior: Cambridge University Press.

Fetzer, T, M Witte, L Hensel, J Jachimowicz, J Haushofer, A Ivchenko, S Caria, E Reutskaja, C Roth, S Fiorin, M Gomez, G Kraft-Todd, F Goetz, and E Yoeli. 2020. "[Pre-print]. Global behaviors and preceptions in the COVID-19 pandemic." doi: 10.31234/osf.io/3kfmh.

Fine, Adam D, Zachary Rowan, and Cortney Simmons. 2019. "Do politics Trump race in determining America's youths' perceptions of law enforcement?" Journal of Criminal Justice 61:48-57.

Fine, Adam, April Thomas, Benjamin van Rooij, and Elizabeth Cauffman. 2020. "Age-Graded Differences and Parental Influences on Adolescents' Obligation to Obey the Law." Journal of Developmental and Life-Course Criminology:1-18.

Fine, Adam, Benjamin Van Rooij, Yuval Feldman, Shaul Shalvi, Margerita Leib, Eline Scheper, and Elizabeth Cauffman. 2016. "Rule Orientation and Behavior: Development and Validation of a Scale Measuring Individual Acceptance of Rule Violation." Psychology, Public Policy, and Law 22 (3):314-329.

Friedman, Lawrence M. 2016. Impact: Harvard University Press.

Gau, Jacinta M. 2014. "Procedural justice and police legitimacy: A test of measurement and structure." American Journal of Criminal Justice 39 (2):187-205.

Gottfredson, Michael R, and Travis Hirschi. 1990. A general theory of crime: Stanford University Press.

Harper, CA, LP Satchell, D Fido, and RD Latzman. 2020. "[Pre-print]. Functional fear predicts public health compliance in the COVID-19 pandemic." doi: 10.31234/osf.io/jkfu3. 
Hasson, Yossi, Maya Tamir, Kea S Brahms, J Christopher Cohrs, and Eran Halperin. 2018. "Are liberals and conservatives equally motivated to feel empathy toward others?" Personality and Social Psychology Bulletin 44 (10):1449-1459.

Hofstede, Geert, Gert Jan Hofstede, and Michael Minkov. 1991. Cultures and organizations: Software of the mind. Vol. 2: McGraw-Hill London.

I\&O Research, and Universiteit Twente. 2020. Rapport: Het Corona- en het eenzaamheidsvirus. Amsterdam: I\&O Research.

Jackson, Jonathan, Krisztian Posch, Ben Bradford, Zoe Hobson, Arabella Kyprianides, and Julia Yesberg. 2020. "The lockdown and social norms: why the UK is complying by consent rather than compulsion." LSE. https://blogs.Ise.ac.uk/politicsandpolicy/lockdown-social-norms/.

Kogut, Tehila, and Ilana Ritov. 2005. "The "identified victim" effect: An identified group, or just a single individual?" Journal of Behavioral Decision Making 18 (3):157-167.

Kooistra, Emmeke, Christopher P. Reinders Folmer, Elke Olthuis, Megan Brownlee, Malouke Esra Kuiper, Adam Fine, and Benjamin Van Rooij. 2020. "Mitigating COVID-19 in a Nationally Representative UKSample: Personal Abilities and Obligation to Obey the Law Shape Compliance with Mitigation Measures." Working Paper posted on PsyArXiv https://psyarxiv.com/zuc23/.

Kuiper, Malouke Esra, Anne Leonore de Bruijn, Christopher P. Reinders Folmer, Elke Olthuis, Megan Brownlee, Emmeke Kooistra, Adam Fine, and Benjamin Van Rooij. 2020. "The intelligent lockdown: Compliance with COVID-19 mitigation measures in the Netherlands." Working Paper posted on PsyArXiv https://psyarxiv.com/5wdb3.

Kushner Gadarian, S, S Wallace Goodman, and TB Pepinsky. 2020. "[Pre-print]. Partisanship, health behavior, and policy attitudes in the early stages of the COVID-19 pandemic." doi: $10.2139 /$ ssrn. 3562796

Lunn, PD, S Timmons, CA Belton, M Barjaková, H Julienne, and C Lavin. 2020. "[Pre-print]. Motivating social distancing during the Covid-19 pandemic: An online experiment." doi: 10.31234/osf.io/x4agb.

McCright, Aaron M, Katherine Dentzman, Meghan Charters, and Thomas Dietz. 2013. "The influence of political ideology on trust in science." Environmental Research Letters 8 (4):044029. doi: 10.1088/1748-9326/8/4/044029/meta.

Mikulincer, Mario, Aron Weller, and Victor Florian. 1993. "Sense of closeness to parents and family rules: A study of Arab and Jewish youth in Israel." International Journal of Psychology 28 (3):323-335.

Nagin, Daniel S. 2013. "Deterrence in the Twenty-first Century." Crime and Justice 42 (1):199-263.

Oosterhoff, B, and CA Palmer. 2020. "[Pre-print]. Psychological correlates of news monitoring, social distancing, disinfecting, and hoarding behaviors among US adolescents during the COVID-19 pandemic." doi: 10.31234/osf.io/rpcy4.

Paternoster, Raymond, and Sally Simpson. 1993. "A rational choice theory of corporate crime." Routine activity and rational choice 5:37.

Plohl, N., and B. Musil. 2020. "[Pre-print]. Modeling compliance with COVID-19 prevention guidelines: The critical role of trust in science." doi: 10.31234/osf.io/6a2cx.

Posch, Krisztian, Jonathan Jackson, Ben Bradford, and Sarah Macqueen. 2020. "' Truly Free Consent"? Clarifying the Nature of Police Legitimacy using Causal Mediation Analysis." Journal of Experimental Criminology.

Pratt, Travis C, and K Lloyd. 2021 (forthcoming). "Self-control and offending." In The Cambridge Handbook on Compliance, edited by B Van Rooij and D Sokol. Cambridge, UK: Cambridge University Press.

Prior, Markus. 2013. "Media and political polarization." Annual Review of Political Science 16:101-127. 
Reisig, Michael D, Jason Bratton, and Marc G Gertz. 2007. "The construct validity and refinement of process-based policing measures." Criminal justice and behavior 34 (8):1005-1028.

Sagy, Shifra, Emda Orr, Dan Bar-On, and Elia Awwad. 2001. "Individualism and collectivism in two conflicted societies: Comparing Israeli-Jewish and Palestinian-Arab high school students." Youth \& Society 33 (1):3-30.

Schultz, P. Wesley, Jessica M. Nolan, Robert B. Cialdini, Noah J. Goldstein, and Vladas Griskevicius. 2007. "The constructive, destructive, and reconstructive power of social norms." Psychological Science 18 (5):429-434.

Spohr, Dominic. 2017. "Fake news and ideological polarization: Filter bubbles and selective exposure on social media." Business Information Review 34 (3):150-160.

Tankebe, Justice, Michael D Reisig, and Xia Wang. 2016. "A multidimensional model of police legitimacy: A cross-cultural assessment." Law and Human Behavior 40 (1):11.

Tyler, Tom. 2017. "Procedural justice and policing: A rush to judgment?" Annual Review of Law and Social Science 13:29-53.

Tyler, Tom R. 1997. "Procedural Fairness and Compliance with the Law." Swiss Journal of Economics and Statistics 133 (2):p. 219-240.

Tyler, Tom R. 2006. Why People Obey the Law. Princeton: Princeton University Press.

Van Rooij, Benjamin. 2021 (Forthcoming). "Do people know the law? Empirical evidence about legal knowledge and its implications for compliance." In Cambridge Handbook of Compliance, edited by Benjamin van Rooij and D Daniel Sokol. Cambridge, UK: Cambridge University Press.

van Rooij, Benjamin, Anne Leonore de Bruijn, Christopher Reinders Folmer, Emmeke Kooistra, Malouke Esra Kuiper, Megan Brownlee, Elke Olthuis, and Adam Fine. 2020. "Compliance with COVID-19 Mitigation Measures in the United States." Working paper on PsyArXiv. doi: 10.31234/osf.io/qymu3.

Van Rooij, Benjamin, Anne Leonore de Bruijn, Christopher P. Reinders Folmer, Emmeke Kooistra, Malouke Esra Kuiper, Megan Brownlee, Elke Olthuis, and Adam Fine. 2020. "Compliance with COVID-19 Mitigation Measures in the United States " Working Paper posted on PsyArXiv psyarxiv.com/qymu3.

Van Rooij, Benjamin, and D Daniel Sokol. 2021 (Forthcoming). "Compliance as the interaction between rules and behavior (Introduction to Cambridge Handbook of Compliance)." In Cambridge Handbook of Compliance, edited by D Daniel Sokol and Benjamin Van Rooij. Cambridge, UK: Cambridge University Press.

Walker, Patrick, Charles Whittaker, Oliver Watson, Marc Baguelin, Kylie Ainslie, Sangeeta Bhatia, Samir Bhatt, Adhiratha Boonyasiri, Olivia Boyd, Lorenzo Cattarino, Zulma Cucunubá, Gina CuomoDannenburg, Amy Dighe, Christl Donnelly, Ilaria Dorigatti, Sabine van Elsland, Rich FitzJohn, Seth Flaxman, Han Fu, Katy Gaythorpe, Lily Geidelberg, Nicholas Grassly, Will Green, Arran Hamlet, Katharina Hauck, David Haw, Sarah Hayes, Wes Hinsley, Natsuko Imai, David Jorgensen, Edward Knock, Daniel Laydon, Swapnil Mishra, Gemma Nedjati-Gilani, Lucy Okell, Steven Riley, Hayley Thompson, Juliette Unwin, Robert Verity, Michaela Vollmer, Caroline Walters, Hao Wei Wang, Yuanrong Wang, Peter Winskill, Xiaoyue Xi, Neil Ferguson, and Azra Ghan. 2020. "The Global Impact of COVID-19 and Strategies for Mitigation and Suppression." Imperial College Covid-19 Reports (12).

Walters, Glenn D, and P Colin Bolger. 2019. "Procedural justice perceptions, legitimacy beliefs, and compliance with the law: A meta-analysis." Journal of experimental Criminology 15 (3):341-372.

Weinberger, Daniel A, and Gary E Schwartz. 1990. "Distress and restraint as superordinate dimensions of self-reported adjustment: A typological perspective." Journal of personality 58 (2):381-417.

Wojcik, Sean P, Arpine Hovasapian, Jesse Graham, Matt Motyl, and Peter H Ditto. 2015. "Conservatives report, but liberals display, greater happiness." Science 347 (6227):1243-1246. 
Wolfe, Scott E, Justin Nix, Robert Kaminski, and Jeff Rojek. 2016. "Is the effect of procedural justice on police legitimacy invariant? Testing the generality of procedural justice and competing antecedents of legitimacy." Journal of quantitative criminology 32 (2):253-282.

Yagil, Dana, and Arye Rattner. 2002. "Between commandments and laws: Religiosity, political ideology, and legal obedience in Israel." Crime, law and social change 38 (2):185-209. 